\title{
High Plant Species Distributed in and around Dengizkul, Bukhara Region
}

\author{
Husniddin Kurbonovich Esanov, Feruz Qamariddinovich Shodmonov, Aziz Mukhtorovich Kobilov \\ Bukhara State University, Bukhara, Uzbekistan \\ Email: husniddin_1978@mail.ru, azizqobilov-87@mail.ru
}

How to cite this paper: Esanov H.K., Shodmonov, F.Q. and Kobilov A.M. (2021) High Plant Species Distributed in and around Dengizkul, Bukhara Region. American Journal of Plant Sciences, 12, 266-273. https://doi.org/10.4236/ajps.2021.122016

Received: December 15, 2020

Accepted: February 23, 2021

Published: February 26, 2021

Copyright $\odot 2021$ by author(s) and ScientificResearch Publishing Inc. This work is licensed under the Creative Commons Attribution International License (CC BY 4.0).

http://creativecommons.org/licenses/by/4.0/

\begin{abstract}
The article presents the results of research conducted in Dengizkul and around this area. It identifies plant species in and around the lake and analyzes species composition. As a result of the analysis, 70 species of tall plants belonging to 24 families were identified in the lake. The identified species are divided into aquatic and riparian plants. Of these, 18 species are found in lake water and 52 species in its vicinity. The low number of high plant species in the lake water is due to the salinity of the water. The protection of this area is based on the natural conservation of the surrounding plant population.
\end{abstract}

\section{Keywords}

Dengizkul, Bukhara, Zarafshan River, Water Basin, High Plants, Water

\section{Introduction}

There are more than 500 lakes in Uzbekistan and they are used wisely for various purposes [1]. A number of studies have been conducted on the hydrobiology of these lakes. However, not all lakes have been fully studied along the waterfront and aquatic plants. One such lake is Dengizkul Lake. Dengizkul is located in the south-west of the Republic of Uzbekistan, in the Alat district of Bukhara region, $75 \mathrm{~km}$ from the city of Bukhara, on the border with Turkmenistan, $40 \mathrm{~km}$ northwest of the center of Alat district (Figure 1). Dengizkul physically and geographically occupies the depth part of the plains of Bukhara region. In the twentieth century, the Zarafshan River played an important role in the formation of the Dengizkul River. The lower tributary of the Zarafshan River, Tayqir, flows into the lake [2]. Currently, the main water source of the lake is the southern Alat collector. In recent years, the salinity of the water has increased significantly as a result of the decrease in the amount of water discharged into the lake. Lake Den gizkul is a reservoir formed as a result of the discharge of water from the Bukhara 


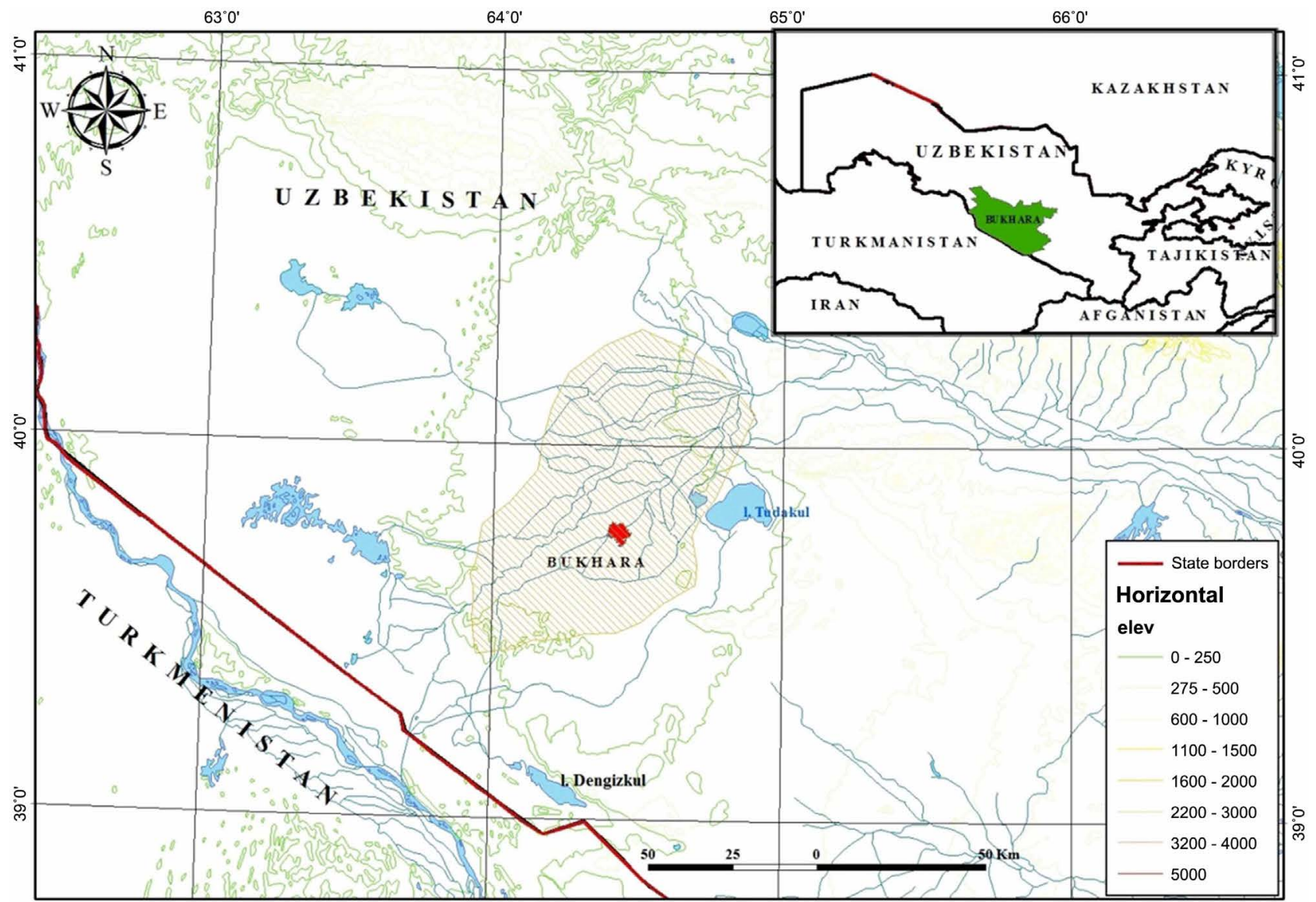

Figure 1. Location of Dengizkul lake.

and Karakul oases through the Khamza collector in the 1960s-1970s on the site of a natural depression [3].

Currently, Dengizkul receives sewage and collector water from Bukhara region. But these waters cannot maintain the water level of the lake permanently. In summer, very hot days cause the lake water to evaporate, and as a result of the decrease in the amount of water, the amount of salt in it increases, leading to the accumulation of salt at the bottom of the lake up to half a meter. The results of such studies serve as a scientific basis for improving the economic development and epidemiological sanitation of these areas.

\section{Literature Review}

Scientists from Central Asia and the Republic of Uzbekistan have conducted a number of scientific studies on aquatic and marine plants. In particular, the aquatic plants found in the Farkhod Reservoir are N.V. Generalov [4], K.V. on the formation of aquatic plants. Dobroxotova [5] [6], data on the ecology of plants distributed in water basins V.S. Pokrovskiy [7], V.V. Nikitin [8] is mentioned in his scientific works. The distribution of aquatic plants T.G. Matyukova [9], A.A. Ashirova [10], V.M. was studiedby Katansky [11] and others. The largest research work on the study of aquatic and coastal plants in Central Asia was con- 
ducted by M.G. Popov, E.P. Korovin, V.P. Drobov, N.V. Pavlov, A.M. Muzafarov, K.Z. Zakirov, L.E. Rodina, I.I. Granitov, F.N. Belongs to Rusanov and others. On the composition of species of plants and their useful properties in the water basins of Uzbekistan and its environs A.M. Muzafarov and others [12], A.E. Ergashev [13], T. Taubaev [14], S. Keldibekov [15], N.E. Rashidov [16] and other scientists. High plants have been studied by Esanov [17] and lists 11 species of water and coastal plant species. Also, the plants of Karakir Lake are studies by A.M. Kobilov and others. [18], Devkhona Lake Plants are studied by A.R. Kuzmetov and others [19].

\section{Research Methodology}

The object of study is the tall plants distributed in and around Lake Dengizkul, Bukhara region. Data from Flora of Uzbekistan [20], Opredelitel rasteniy Sredney Azii [21] and Analysis of Flora of Bukhara Oasis [22] were used to determine the composition of plant species. Herbarium specimens were collected by the route [23] method. The scientific names of the categories and species are "Opredelitel rasteniy Sredney Azii" [21], according to international indexes-International Plants Names Index [24], The Plant List [25] and the authors of the species Brummit, R.K., Powell, C.E. [26]. The map of Bukhara region was created on the basis of ArcGIS 10 program.

\section{Research Results}

In existing scientific sources [2] [20] [21] [27] Dengizkul data on marine vegetation have been provided. Some information about the plants is given only in the reports. Therefore, the water and waterfront vegetation of the lake in 2019-2020 were studied. Preliminary results of the study showed that due to the high salinity of the lake water, there were very few species of aquatic plants in it. It can be seen that the natural populations of higher plant species around Dengizkul Lake are very well preserved (Figure 2).

Due to the fact that this area is the object of Lukoil, it was studied on the basis of the collection of herbarium samples during the study that the lands are protected and the plant population is naturally preserved. Calligonium matteianum Drobow, C. paletzkianum Litv., C. setosum Litv., included in the Red Data Book of Uzbekistan, are very rare in this region and species encountered. As a result of the research, the collected plants were systematically analyzed and an initial list of species was compiled. They were divided into groups according to their meeting in the water and on the waterfront (Table 1).

Table 1. Plants which are separated in Dengizkul.

\begin{tabular}{ccc}
\hline Type of vegetation & $\begin{array}{c}\text { Water } \\
\text { growing }\end{array}$ & $\begin{array}{c}\text { Water along } \\
\text { growing }\end{array}$ \\
\hline Ephedraceae & \\
\hline \\
Ephedra strobilacea Bunge & + \\
\hline
\end{tabular}




\section{Continued}

\begin{tabular}{|c|c|c|c|}
\hline & Ceratophyllaceae & & \\
\hline \multirow[t]{2}{*}{2} & Ceratophyllum demersum $L$. & + & \\
\hline & Ranunculaceae & & \\
\hline 3 & Ceratocephala falcata (L.) Pers. & & + \\
\hline 4 & Consolida leptocarpa Nevski & & + \\
\hline 5 & Consolida camptocarpa (Fisch. \& C.A.Mey. ex Ledeb.) Nevski & & + \\
\hline \multirow[t]{2}{*}{6} & Acanthophyllum elatius Bunge & & + \\
\hline & Papaveraceae & & \\
\hline 7 & Roemeria refracta (Stev.) DC. & & + \\
\hline \multirow[t]{2}{*}{8} & Papaver pavoninum Schrenk & & + \\
\hline & Chenopodiaceae & & \\
\hline 9 & Agriophyllum latifolium Fisch. et C.A. Mey. & & \\
\hline 10 & Atriplex dimorphostegia Kar. et Kir. & & + \\
\hline 11 & Atriplex tatarica $L$. & & + \\
\hline 12 & Chenopodium album $L$. & & + \\
\hline 13 & Climacoptera sukaczevii Botsch. & & + \\
\hline 14 & Corispermum korovinii Iljin & & + \\
\hline 15 & Halimocnemis latifolia Iljin & & + \\
\hline 16 & Halocnemum strobilaceum (Pall.) M. Bieb. & & + \\
\hline 17 & Halostachys bélangeriana (Moq.) Botsch. & & + \\
\hline 18 & Halothamnus subaphyllus (C.A.Mey.) Botsch. & & + \\
\hline 19 & Haloxylon persicum Bunge & & + \\
\hline 20 & Horaninovia ulicina Fisch. et C.A. Mey & & + \\
\hline 21 & Kalidium caspicum (L.) Ung.-Sternb. & & + \\
\hline 22 & Salsola incanescens C. A. Mey. & & + \\
\hline 23 & Salsola richterii (Moq.) Kar. ex Litv. & & + \\
\hline \multirow[t]{2}{*}{24} & Suaeda crassifolia Pall & & + \\
\hline & Polygonaceae & & \\
\hline 25 & Polygonum persicaria $L$. & + & \\
\hline \multirow[t]{2}{*}{26} & Polygonum aviculari $L$. & & + \\
\hline & Plumbaginaceae & & \\
\hline \multirow[t]{2}{*}{27} & Limonium meyeri (Boiss.) Kuntze. & & + \\
\hline & Tamaricaceae & & \\
\hline 28 & Tamarix hispida Willd. & & + \\
\hline \multirow[t]{2}{*}{29} & Tamarix ramosissima Lab. & & + \\
\hline & Brassicaceae & & \\
\hline \multirow[t]{2}{*}{30} & Arabidopsis pumila (Steph.) N.Busch & & + \\
\hline & Fabaceae & & \\
\hline
\end{tabular}




\section{Continued}

\begin{tabular}{|c|c|c|c|}
\hline 31 & Alhagi pseudalhagi (M.B.) Desv. & & + \\
\hline 32 & Astragalus chiwensis Bunge & & + \\
\hline 33 & Astragalus unifoliatus Bunge & & + \\
\hline 34 & Astragalus villosissimus Bunge & & + \\
\hline \multirow[t]{2}{*}{35} & Smirnovia turkestana Bunge & & + \\
\hline & Haloragaceae & & \\
\hline 36 & Myriophyllum spicatum $L$. & + & \\
\hline \multirow[t]{2}{*}{37} & Myriophyllum verticilatum $L$. & + & \\
\hline & Asteraceae & & \\
\hline 38 & Acroptilon repens (L.) D.C. & & + \\
\hline 39 & Hyalea pulchella (Ledeb.) K.Koch & & + \\
\hline 40 & Karelinia caspia (Pall.) Less. & & + \\
\hline 41 & Lactuca tatarica (L.) Cam. & & + \\
\hline 42 & Paramicrorhynchus procumbens (Roxb.) Kirp & & + \\
\hline \multirow[t]{2}{*}{43} & Senecio subdentatus Ledeb. & & + \\
\hline & Apocynaceae & & \\
\hline \multirow[t]{2}{*}{44} & Cynanchum sibiricum Willd. & & + \\
\hline & Convolvulaceae & & \\
\hline 45 & Convolvulus divaricatus Regel \& Schmalh. & & + \\
\hline \multirow[t]{2}{*}{46} & Convolvulus arvensis $\mathrm{L}$. & & + \\
\hline & Boraginaceae & & \\
\hline 48 & Arnebia decumbens (Vent.) Coss. \& Kralik & & + \\
\hline \multirow[t]{2}{*}{49} & Heliotropium arguzioides Kar. et Kir. & & + \\
\hline & Plantaginaceae & & \\
\hline \multirow[t]{2}{*}{50} & Plantago lanceolata $L$. & & + \\
\hline & Lamiaceae & & \\
\hline \multirow[t]{2}{*}{51} & Chamaesphacos ilicifolius Schrenk & & + \\
\hline & Juncaceae & & \\
\hline 52 & Juncus articulates L. & + & \\
\hline \multirow[t]{2}{*}{53} & Juncus gerardii Loisel. & + & \\
\hline & Butomaceae & & \\
\hline \multirow[t]{2}{*}{54} & Butomus umbellatus $L$. & + & \\
\hline & Cyperaceae & & \\
\hline 55 & Bolboschoenus popovii T.V. Egorova & + & \\
\hline 56 & Cyperus rotundus L. & & + \\
\hline 57 & Scirpus mucronatus $\mathrm{L}$. & + & \\
\hline \multirow[t]{2}{*}{58} & Scirpus triqueter $\mathrm{L}$. & + & \\
\hline & Poaceae & & + \\
\hline
\end{tabular}




\begin{tabular}{ccc} 
Continued & & \\
\hline 59 & Cynodon dactylon (L.) Pers. & + \\
60 & Aeluropus litoralis (Gouan) Parl. & + \\
61 & Calamagrostis dubia Bunge. & + \\
62 & Echinochloa crus galli R. et. Sch. & + \\
63 & Phragmites astralis $($ L.) Trin. & + \\
64 & Erianthus ravennae (L) P. Beauv. & + \\
& Najadaceae & + \\
65 & Najas marina L. & + \\
66 & Potamogetonaceae & + \\
67 & Potamogeton crispus L. & \\
& Potamogeton perfoliatus L. & + \\
68 & Typhaceae & + \\
70 & Typha angustifolia L. & + \\
& Typha laxmannii Lepech. & +
\end{tabular}

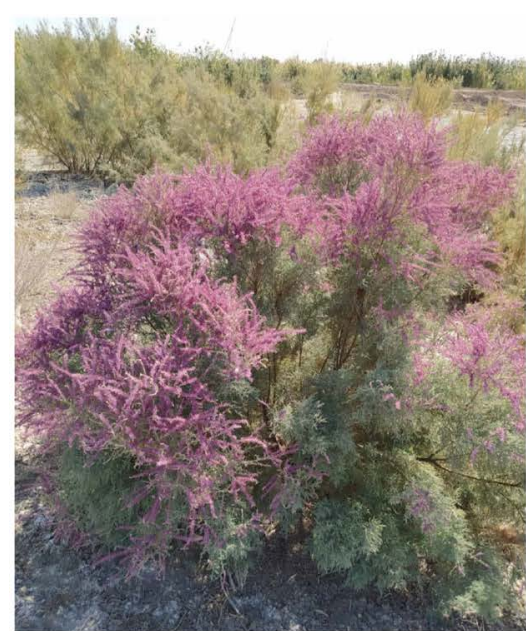

Tamarix ramosissima Ledeb.

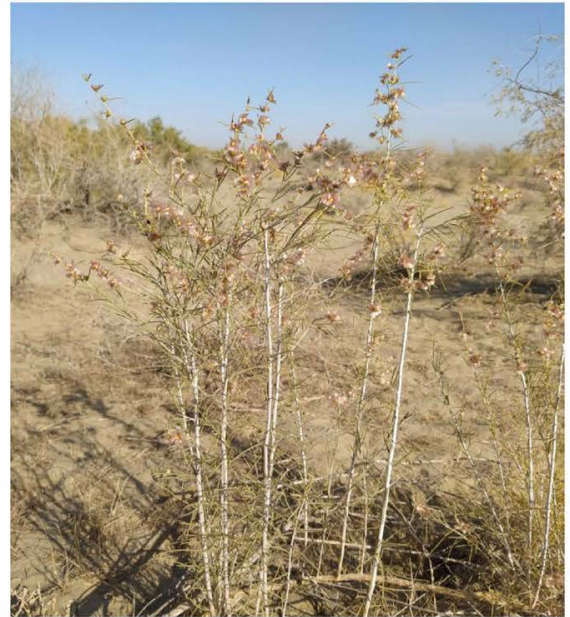

Salsola richterii (Moq.) Kar. ex Litv.

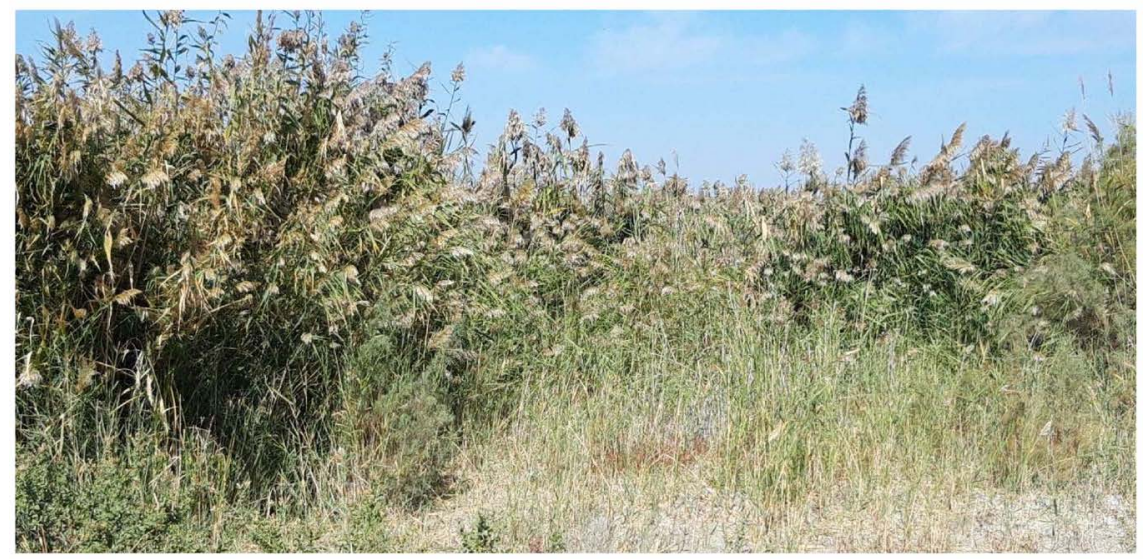

Phragmites astralis (L.) Trin.

Figure 2. Natural population of around Dengizkul. 
In this region 70 species of tall plants belonging to 24 families have been identified. Of these, 18 species are found in lake water and 52 species in its vicinity. Unlike other lakes in Bukhara region, the number of aquatic plant species was small.

\section{Conclusion}

Lake Dengizkul was rich in flora and fauna in the early days of its emergence. However, in recent years, the decrease in the amount of water discharged into the lake and the strong transpiration process have increased the salinity of the water, leading to a decrease in the number of higher aquatic plants. The number of species in this lake was lower than in other lakes of Bukhara region. Even Phragmites australis and Typha angustifolia, which are recorded as the main plant of all lakes, can be found only in some parts of the lake shores. The population of terrestrial plants around the sea is naturally preserved and rich in species.

\section{Conflicts of Interest}

The authors declare no conflicts of interest regarding the publication of this paper.

\section{References}

[1] United Nations Economic Commission for Europe and Regional Environmental Centre for Central Asia (2011) Development of Regional Cooperation to Ensure Water Quality in Central Asia: Diagnostic Report and Development Cooperation Plan. United Nations, New York, 7-10.

[2] Sedov, V.V. (1959) Floodplain Vegetation of the Zerafshan Valley and the Ways of Its Reconstruction. Uzbek State University, Samarkand, 79.

[3] Mitropolskiy, M. (2020) Rapid Assessment of Wetlands in Uzbekistan, Dengiz-Kul Lake. https://www.carececo.org/

[4] Generalova, V.N. (1947) Materials on the Hydroflora of Reservoirs in the Flood Zone of the Farhad Reservoir. Academy of Sciences of the UzSSR, Bulletin No. 12, Moscow.

[5] Dobrokhotova, K.B. (1952) Botanical Characteristics of Reservoirs of the Ili River delty. Moscow.

[6] Dobroksotova, K.B. (1954) The Importance of Aquatic Vegetation in the Evolution of Spawning Reservoirs in the Delta of the Amudari. Proceedings of the Laboratory of Lake Science of the USSR Academy of Sciences, Moscow, 57-60.

[7] Pokrovsky, V.S. (1953) Kupachnye Rafts in the Delta of the River, Amu-Darya. Academy of Sciences of the Turkmen SSR, Aşgabat.

[8] Nikitin, V.V. and Meshcheryakov, A.A. (1954) Aquatic and Coastal Vegetation of the Murghab Reservoirs, in the Book.

[9] Matyukova, T.G. (1955) Preliminary Results of the Study of Aquatic Coastal Vegetation in the Tyup Bay of Lake Issyk-Kul. Kyrgyz State University, Bishkek.

[10] Ashirova, A.A. (1958) Materials for the Knowledge of the Vegetation of a Floodplain Lake in the Middle Reaches of the Amudari. Academy of Sciences of the 
Turkmen SSR, Aşgabat.

[11] Katanskaya. V.M. (1959) Aquatic Vegetation of the Amudari Delta. Proceedings of the Laboratory of Lake Science, 2, 8.

[12] Muzafarov, A.M. and Musaev, K.Y. (1961) Materials for the Flora of Algae in the Storage Water of the Zarafshon River Basin. Tashkent State University, Toshkent, 235-249.

[13] Ergashev, A.E. (1960) On the Vegetation of the Collective Network of the Bukhara Region. Toshkent, 3, 23-26.

[14] Taubaev, T.T. (1970) Flora and Vegetation of Water Bodies of Central Asia. Fan, Toshkent, 490.

[15] Keldibekov, S. (1981) Flora and Vegetation of Fish Farms Chirchik-Angren Basin. Fan, Toshkent, 15-22

[16] Rashidov, N.E. (2007) Algoflora of Bukhara Collectors. Doctor of Philosophy Biology Dissertation, Toshkent, 101.

[17] Esanov, H.K. (2016). New Plant Species in the Flora of Bukhara Oasis. Turczaninowia, 19, 77-81. https://doi.org/10.14258/turczaninowia.19.2.10

[18] Kobilov, A.M., Buriev, S.B., Esanov, H.Q. and Yuldoshov, L.T. (2020) Distribution and Taxonomy of High Plant Species in Lake Karakir Bukhara Region. American Journal of Plant Sciences, 11, 589-594. https://doi.org/10.4236/ajps.2020.114044

[19] Kuzmetov, A.R., Toshov, H.M., Esanov, H.K. and Isroilov S.U. (2019) The Species Composition of High-Water Plants and Their Significance in Lake Devkhona, Bukhara Region. Bulletin of the Agricultural Science of Uzbekistan, 2, 138-141.

[20] Editorial Team (1941-1962) Flora of Uzbekistan. Editio Academiae Scientiarum UzSSR, Tashkent.

[21] Editorial Team (1968-1993) Conspectus Florae Asiae Mediae, 1968-1993. FAN, Tashkent.

[22] Esanov, H.K. (2017) Flora Analysis of the Bukhara Oasis. Doctor of Philosophy Biology Dissertation, Tashkent, 179.

[23] Shcherbakov, A.V. and Mayorov, S.R. (2006) Inventory of Flora and the Basics of Herbarium (Methodical Recommendations). Partnership of Scientific Publications KMK, Moscow, 48.

[24] International Plant Names Index (n.d.). http://www.ipni.org

[25] The Plant List (2013). http://www.theplantlist.org/tpl1.1/record/gcc-133949

[26] Brummit, R.K. and Powell, C.E. (1992) Authors of Plant Names. Royal Botanic Gardens, Kew, 732.

[27] Zakirov, K.Z. (1961) Flora and Vegetation of the Zarafshan River Basin. Editio Academiae Scientiarum UzSSR, Tashkent, 654. 